\title{
ENVIRONMENTAL CHANGES AND HUMAN IMPACT ON HOLOCENE EVOLUTION OF THE HORODYSKA RIVER VALLEY (LUBLIN UPLAND, EAST POLAND)
}

\author{
RADOSŁAW DOBROWOLSKI ${ }^{1}$, IRENA AGNIESZKA PIDEK ${ }^{1}$, STANISLAW GOLUB ${ }^{2}$, \\ TOMASZ DZIEŃKOWSKI ${ }^{2}$ \\ ${ }^{1}$ Institute of Earth Sciences, Maria Curie-Skłodowska University, Kraśnicka 2 cd, PL-20-718 Lublin, Poland \\ ${ }^{2}$ Archaeological Service, Wspólna str. 25, PL-22-100 Chetm, Poland
}

Received 21 May 2009

Accepted 11 December 2009

\begin{abstract}
Interdisciplinary palaeoenvironmental studies, conducted near the multi-cultural archaeological sites in the Horodyska River valley (Lublin Upland, East Poland), enable to reconstruct natural and anthropogenic changes of fluvial landscape in the Holocene. The changes are evidenced by the results of archaeological, geological, sedimentological and palynological investigations, as well as radiocarbon and thermoluminescence dating. The Horodyska fluvial system started functioning at the turn of the Late Vistulian and Preboreal. From the beginning of the Subatlantic the record of environmental changes in valley deposits bears the mark of human impact. Main phases of settlement on the river valley bottom (higher terrace) correspond to rather dry periods (Neolithic, Bronze Age, Halstadt period, period of Roman influence, early Middle Ages). Moistening of climate and its associated rise of groundwater level forced people to move settlement on the loess plateau and found a stronghold at the turn of the 11 th and 12 th centuries.
\end{abstract}

Keywords: palaeoenvironmental changes, human impact, fluvial landscape, Holocene, Lublin Upland

\section{INTRODUCTION}

River valleys, because of fluvial environment specificity, belong to especially valuable and at the same time difficult to interpret objects recording climatic changes and signs of intensive human activity. Irrespective of their hydrological rank and morphologic distinctiveness, they were the main zones of human settlement both in the prehistory and Middle Ages. This fact resulted to the same extent from the proximity of water favouring easy water management and from the strategic-defensive reasons that were conditioned by usually diversified morphology of valley bottoms. In the European scale it is documented by numerous archaeological sites concentrated exactly in river valleys, both large - of regional rank (see e.g.; Zolitschka et al., 2003; Chudziak et al., 2004; Kalicki, 2006) and small - of local importance (Okuniewska and Tobolski, 1981; Nowaczyk and Okuniewska-Nowaczyk, 1991; Nalepka, 1994; Stupnicka et

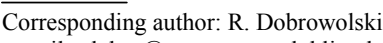
e-mail: rdobro@poczta.umcs.lublin.pl

ISSN 1897-1695 (online), 1733-8387 (print) (C) 2010 GADAM Centre, Institute of Physics, Silesian University of Technology.

All rights reserved. al., 2006; Hoczyk-Siwkowa, 2006). However, the character of human management in river valleys was mostly influenced by climatic and hydrological changes occurring in the environment during the whole Holocene (Starkel, 1977, 2002; Kalicki, 1996, 2006; Stupnicka et al., 2006). These changes also significantly determined the location of settlements (bottoms and sides of valleys, higher terraces or the areas outside the valleys). Therefore, the sites that are archaeologically well examined and palaeogeographically documented in detail, especially those representing long-lasting settlement phase, enabled full analysis of interactions between natural factors and human activity occurring in the environment in a long period (Łanczont et al., 2006).

Interdisciplinary studies of similar extent were undertaken in the Horodyska River valley (Lublin Upland, East Poland) with numerous documented sites of the prehistoric and early Middle Ages settlement. The purpose of the work is to reconstruct in detail the environmental (humidity-thermic and hydrological) conditions in the valley surroundings, based on the analysis of archaeological, geological (sedimentological), and palaeobotanical data, supplemented with the results of radiocarbon 
and thermoluminescence dating. The object of special interest is the reconstruction of interrelations between human activity and natural environment of the examined area.

\section{GEOLOGICAL AND GEOMORPHOLOGICAL SETTING}

The studied area is located in the eastern part of the Lublin Upland, within the Grabowiec Height subregional unit (Fig. 1). Typical landscape feature of this region, determining its physiographic identity, is the occurrence of sub-latitudinal trains of hills composed of harder kinds of the Upper Cretaceous rocks (mostly opokas) and sepa- rating them narrow valleys developed mostly in the outcrop zones of soft marls and chalk (Fig. 2A). The hills, rising about 40-80 $\mathrm{m}$ over the level of modern river valleys (Wojsławka, Horodyska, Rakołupka), are covered with the thick - in places to $10 \mathrm{~m}$ - mantle of the Vistulian loesses (Fig. 2B). Their slopes are dissected by the net of dry erosion-denudation valleys of Late Vistulian origin and Holocene gullies, especially numerous in continuous loess cover. Near the mouths of these forms, on the bottoms of the Horodyska and Wojsławka river valleys, alluvial fans were formed that are well visible in morphology (Fig. 2B). The Horodyska River valley is rather wide (about 500-700 m) in its upper and middle reaches, and distinctly asymmetric. Their western sides

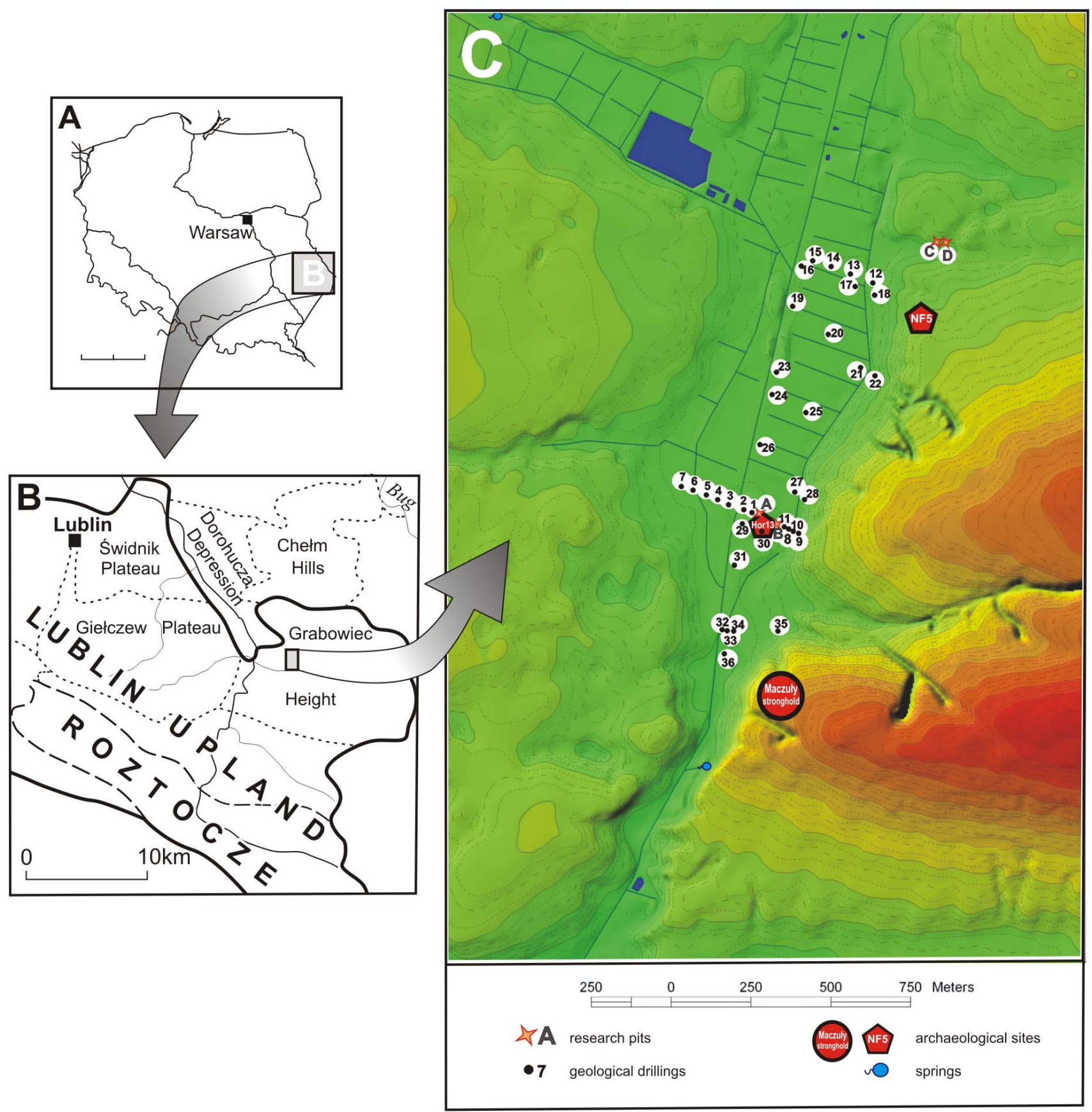

Fig. 1. Location sketch of the study area against the background of Poland (A), eastern part of the Lublin Upland (B), digital model of relief in the Horodyska River valley (after Zagórski, 2008) (C) with the distribution of archaeological sites and geological drillings. 


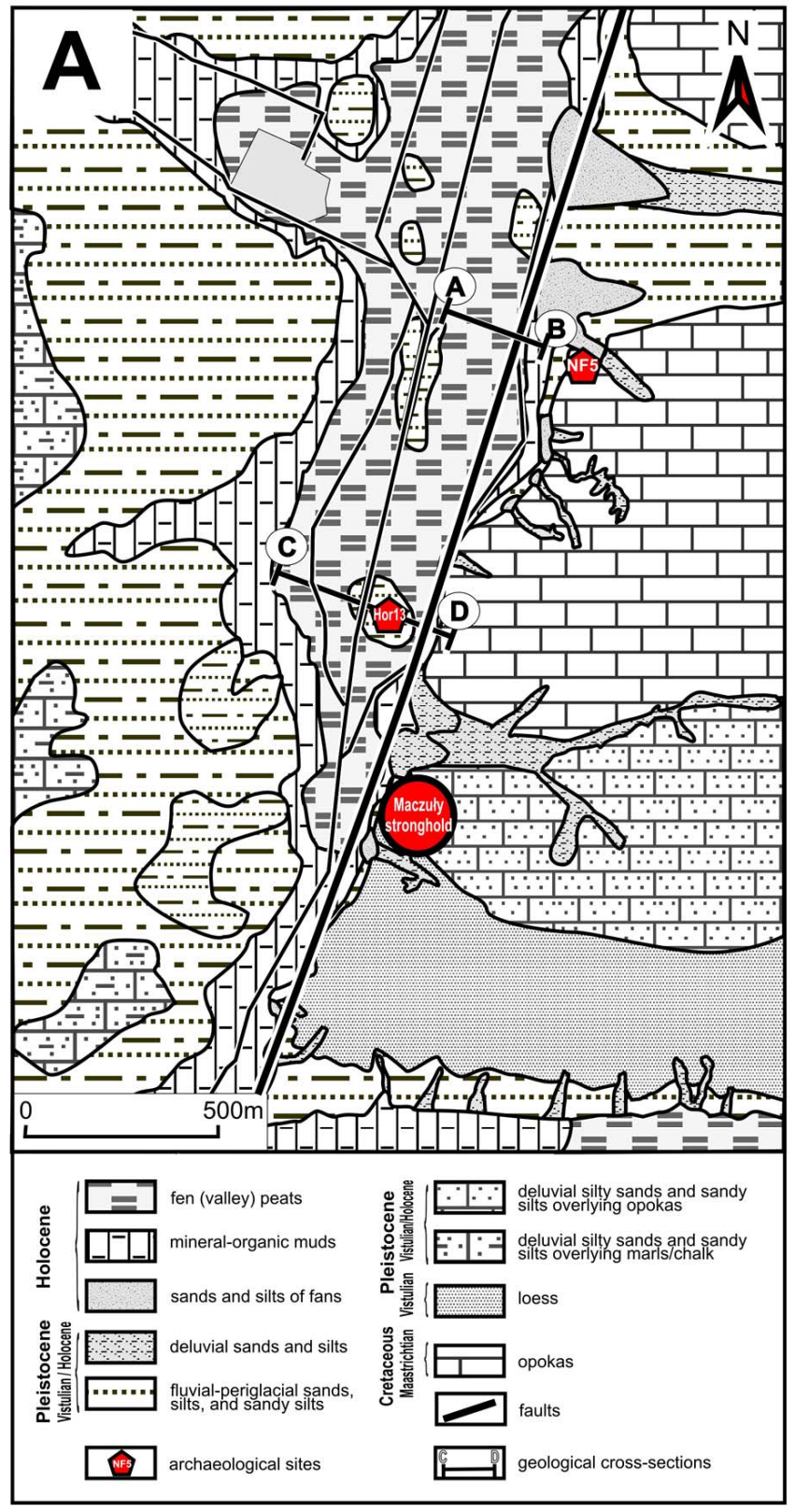

Fig. 2. Geological (A) and geomorphological (B) sketch of the study area.

are gentle, and steep eastern sides form in places a several metres high edge exposing the Upper Cretaceous carbonate-siliceous rocks (Fig. 2 A, B). Tectonic origin of this edge is connected with the Young Alpine Horodysko fault (see Cieśliński and Rzechowski, 1997; Marszałek, 2004). The lower, mouth section of the Horodyska River valley is of gap nature; it is narrow $(50-100 \mathrm{~m})$ with relatively steep slopes. The valley bottom is mainly composed of sedge and sedge-reed fen peat (mostly in the upper and middle reaches) and mineral-organic muds (mostly in the lower reaches). The Late Vistulian higher terrace of the Horodyska River occurs at 205-215 m a.s.1. (5-15 $\mathrm{m}$ over the river level). It forms a wide, continuous, slightly inclined surface along the western side of the valley and a narrow, discontinuous ledge along its eastern side. Small, isolated islands of this terrace occur also on the bottom of the Horodyska River valley (Fig. 2 A, B); a multi-cultural settlement was located on one and existed

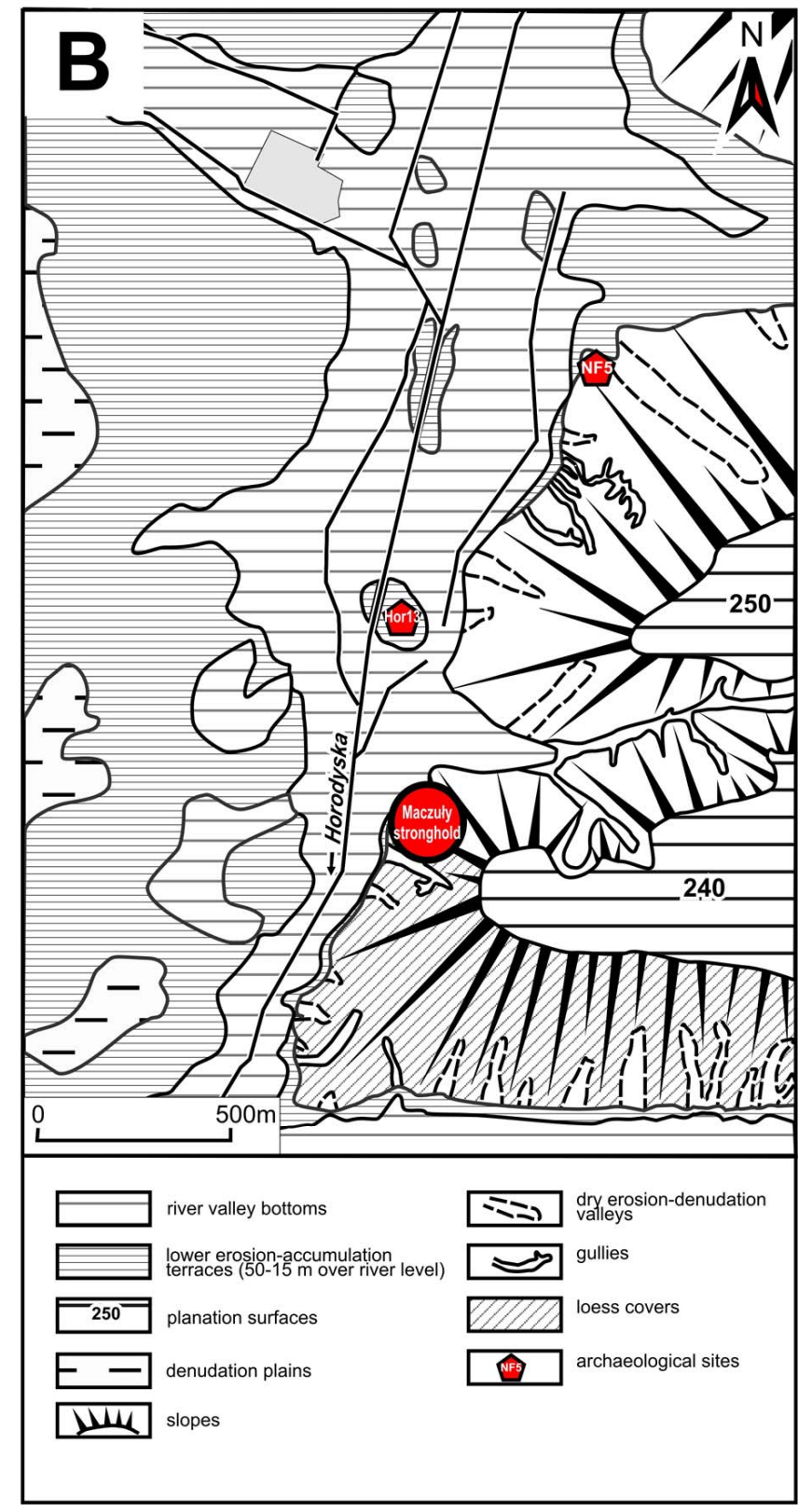

with breaks since the Neolithic to the early Middle Ages (Horodysko - site No 13).

\section{MATERIAL AND METHODS}

Analyses and the resulting palaeoenvironmental interpretations based on detailed archaeological, geological (sedimentological), and palaeobotanical data, supplemented with the results of radiocarbon dating of wood and organic deposits and thermoluminescence dating of pottery and mineral deposits. Interdisciplinary studies were carried out in the years 2004-2007.

\section{Archaeological analysis}

Archaeological investigations were conducted in two sites situated in the middle reaches of the Horodyska River valley. Two-year rescue excavations (2004-2005) 


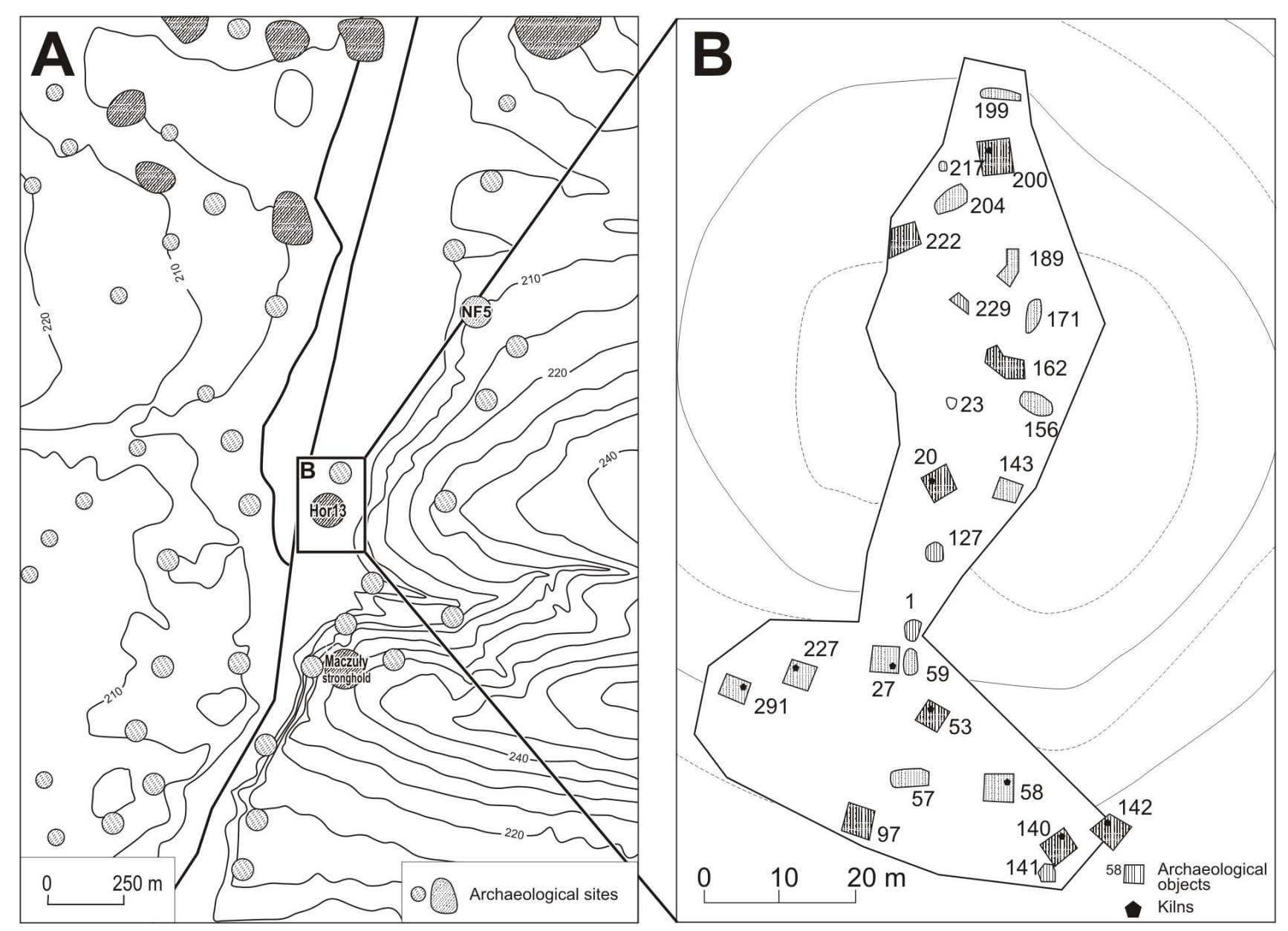

Fig. 3. Distribution of the archaeological sites in the study area from Neolithic to Early Middle Ages after the Archaeological Survey of Poland (A), and the planigraphy of the Early Medieval archaeological objects in the site Hor-13 after the authors' own investigations (B).

were carried out in the Horodysko village in the multicultural site No 13 (location as in Fig. 1, 3), which was in danger of destruction by the planned construction of storage reservoir. Additional archaeological investigations were conducted in 2007 in the degraded site No 5 in the Nowy Folwark village (location as in Fig. 1, 3). Shallow drillings carried out in both sites were aimed at finding settlement concentration and its preliminary examination. Because of large number of objects in the site No 13 , the excavations covered the whole area $(0.5$ ha in total) of the central island (= transversal bar). In the site No 5 in Nowy Folwark the archaeologically investigated area was $650 \mathrm{~m}^{2}$.

\section{Geological analysis}

The scope of research included general geological and geomorphological survey in the direct vicinity of the middle reaches of the Horodyska River valley, and detailed lithofacial analysis of deposits: (a) mineral (in exposures), (b) biogenic (in drill cores with undisturbed deposit structure). Lithofacial analysis of mineral deposits was carried out according to the general methodical principles published by Miall $(1977,1978)$ and Eyles et al., (1983). Biogenic deposits were additionally described using the non-genetic code proposed by Troels-Smiths (1955, after Tobolski, 2000). The results were used to reconstruct the conditions of deposition and for genetic interpretation of post-depositional deformation structures. During field works 36 geological drillings were carried out (using the Eijkelkamp peat-sampler with the box diameter of $5 \mathrm{~cm}$ ) in the valley bottom along the selected sections and 4 research pits in the valley mineral deposits (Fig. 1C). The core of organogenic deposits (Hor-8; $50^{\circ} 57^{\prime} 17.20^{\prime \prime} \mathrm{N} ; 23^{\circ} 26^{\prime} 43.52^{\prime} \mathrm{E}$ ) for palynological analysis and radiocarbon dating was taken in the eastern palaeochannel of the Horodyska River (Fig. 1C, 4), near the archaeological site No 13.

\section{Pollen analysis}

For pollen analysis there were collected 34 samples with the volume of $2 \mathrm{~cm}^{3}$ from the core Hor- 8 . Samples were taken every $10-35 \mathrm{~cm}$, depending on macroscopic lithofacial diversity of deposits. After preliminary microscopic analysis of sporomorphs there were taken additional samples (every $5 \mathrm{~cm}$ ) from the deposits occurring at a depth of 1.90-1.30 m where the percentage of anthropogenic indicators was the highest.

Samples were subjected to standard Erdtman's acetolysis after removing of carbonates (in $10 \% \mathrm{HCl}$ ), organic matter (boiling in $3.5 \% \mathrm{KOH}$ ), and mineral matter (in 40\% HF) (Berglund and Ralska Jasiewiczowa, 1986). 

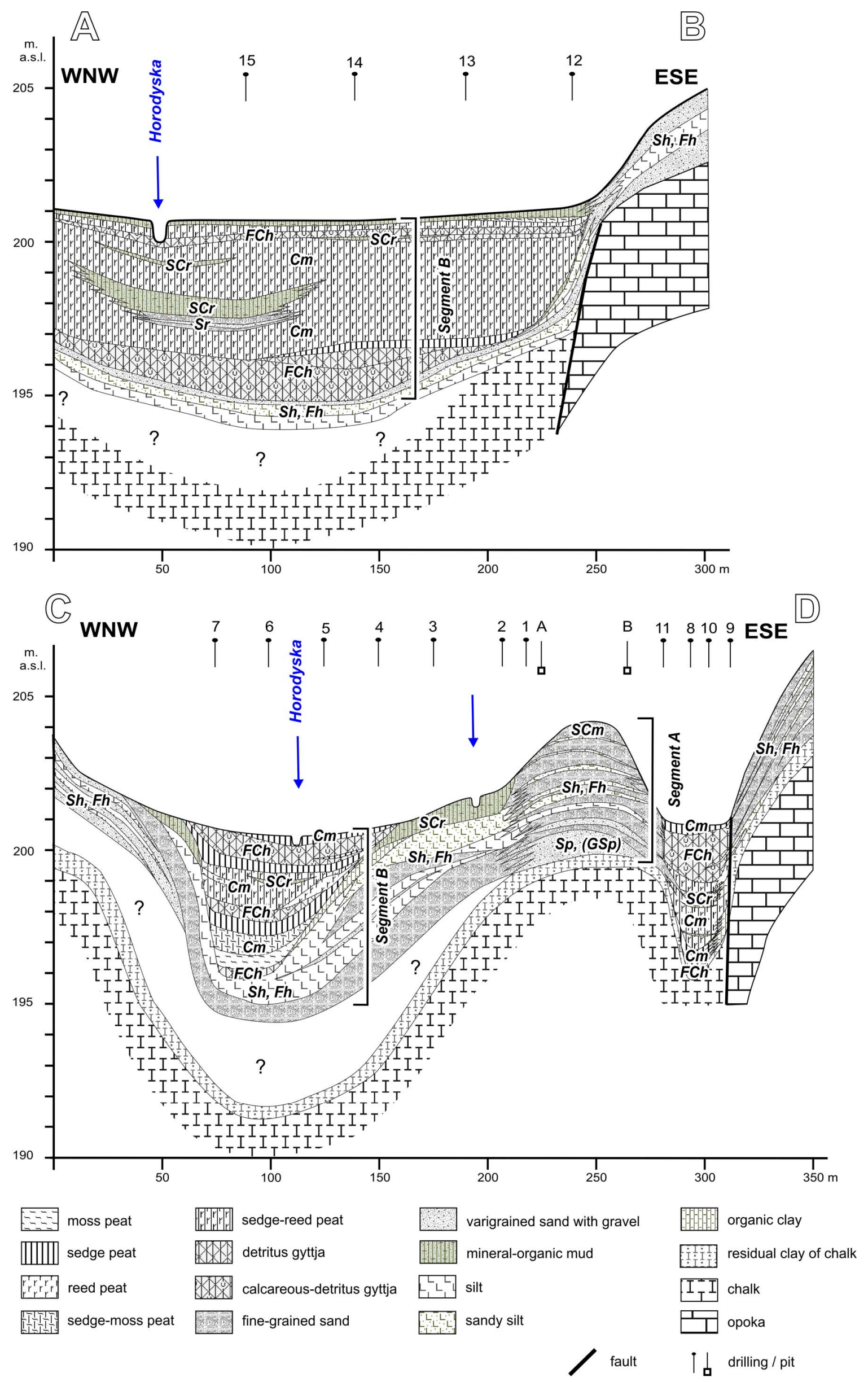

Fig. 4. Geological cross-sections of the Horodyska River valley near the archaeological sites Hor-13 and NF-5; location as in Fig. 1C. 
Pollen spectra were counted on at least two slides. The calculations of pollen and spore percentages were based on the sum of pollen grains of trees and shrubs (AP) and of dwarf shrubs and terrestrial herbs (NAP). Pollen of aquatic and lakeshore vegetation, spores of Pteridophyta and Bryophyta, and colonies of Pediastrum, Botryococcus and Tetraedron algae were excluded from this sum. In the bottom samples (5.00-4.25 m), with high frequencies of sporomorphs, this sum was 700-900 pollen grains (AP+NAP). In the rest of samples an attempt was made to reach at least 500 pollen grains (AP+NAP). Lower sum was counted in the samples taken from a depth of $3.40-2.50 \mathrm{~cm}$ and $1.2 \mathrm{~m}$ because of weak frequencies and bad state of preservation of sporomorphs due to high content of silt.

\section{Radiocarbon dating}

The series of valley biogenic deposits with the highest content of organic matter (detritus gyttja, peats, and wood) were radiocarbon dated. For the core Hor- 8 $\left(50^{\circ} 57^{\prime} 17.20^{\prime \prime} \mathrm{N} ; 23^{\circ} 26^{\prime} 43.52^{\prime \prime} \mathrm{E}\right)^{1}$ there were made 4 conventional measurements of isotope age.

\section{TL dating}

Thermoluminescence method was applied to determine the age of 17 fragments of pottery found in two sites (Horodysko No13 and Nowy Folwark No5) and 2 samples of fluvial deposits composing the higher terrace in the Horodyska River valley. ${ }^{2}$ TL age determination methods follow Buko et al. (2008).

\section{RESULTS}

\section{Archaeological analysis}

In the research site No 13 there were discovered 292 objects of different function and age, and 7 ossuaries. Among 20519 finds there are pottery, flint and stone tools, glass, iron, and bronze artefacts, coins (Fig. 3). These settlement remains date from the following periods:

- Neolithic (about 5000-2200/2300 yr BC) - Linear Pottery Culture, Lublin-Volhynia Culture, Funnel Beaker Culture, Globular Amphora Culture;

- Bronze Age (about 2200/2300-1100 yr BC) Strzyżów Culture, Trzciniec Culture;

- Halstadt period (about 700-400 yr BC) - Lusatian Culture;

- younger Pre-Roman period (300 yr BC to the beginning of new era) - Przeworsk Culture;

- Early Roman period and Late Roman period (from the beginning of new era to $400 \mathrm{yr}$ AD) - Przeworsk Culture;

- $\quad$ early Middle Ages (600-900 AD).

1 Radiocarbon ages were determined in the Radiocarbon Laboratory, Institute of Physics, Silesian University of Technology

${ }^{2}$ TL dating was carried out by Dr Jarosław Kusiak in the Department of Physical Geography and Palaeogeography, Institute of Earth Sciences, Maria CurieSkłodowska University, Lublin.
The most intensive settlement, confirmed by numerous objects and artefacts, developed in the younger PreRoman period (49\% of finds) and early Middle Ages (22.5\% of finds). Settlement of smaller scale occurred in the Roman period (13.5\% of finds). Little intensive settlement was also in the Neolithic (5.5\% of finds), early Bronze Age ( $4.5 \%$ of finds), and Halstadt period ( $0.8 \%$ of finds $)^{3}$. Settlement dated from the Stone Age was discovered in the northern part of the examined hill in the form of pits. Their function can be preliminary determined as utility one. Fragments of earthen pots and animal bone leftovers occur in their fills. The ossuaries of Strzyżów Culture date from the early Bronze Age. Three graves, with skeletons lying along the W-E line with heads to the east, are characterized by rich equipment, i.e. earthen pots (amphorae, bowl, cup) and faience beads. Two next graves differ in the position of skeletons - they lie on their sides along the N-S line. Two graves without skeletons but with equipment (flint tools and earthen pots) are very interesting from the scientific aspect. The other settlement traces connected with the early Bronze Age are related to the Trzciniec Culture. Settlement from the Pre-Roman and Early Roman periods is represented by dwelling and outbuilding objects occurring in the whole area of the site. Two Roman denars dating from the 2 nd and 3rd centuries of new era and fragments of thrown pots dating from the Late Roman period are very interesting and rare finds. The youngest settlement phase with the best-preserved objects is represented by the remains of early Middle Ages settlement from the pre-state period. In the early Slavic period in the southern part of the hills there occurred a group of 5 quadrangular overground dwellings and 2 semi-subterranean huts with heating kilns built of local limestone. The remains of buildings situated around the unoccupied central area are found on the hilltop. The younger settlement phase is represented by three groups of dwelling objects in the form of semisubterranean huts and tub-like pits accompanied by a well.

Archaeological investigations in Nowy Folwark confirmed multi-cultural nature of the site No 5 though settlement had slightly smaller extent and intensity. There were found structures connected with settlement of the Neolithic Globular Amphora Culture and the remains of two early Slavic overground dwellings with remains of kilns.

Therefore, the results of surface investigations and excavations confirm both intensity and continuity of settlement in the Horodyska River valley from the Neolithic to the early Middle Ages. They also indicate that settlement used to a maximum degree both the bottom and sides of the valley.

\section{Geological analysis}

The gathered documentary materials enabled us: (1) to determine thickness and lithofacial type of deposits filling the bottom of the Horodyska River valley, which form the basis for lithogenetic correlation of deposits (Fig. 4); (2) to identify the environmental conditions of

\footnotetext{
${ }^{3}$ The rest of finds $(4.2 \%)$ was not chronologically determined.
} 
location of the multi-cultural settlement (Neolithic-early Middle Ages) in the Horodyska River valley; (3) to reconstruct the changes of organogenic deposition near the examined archaeological sites in order to discuss human influence on the environment during the last 5000 years at least.

\section{Lithofacial characteristics of deposits}

\section{Segment A - Late Glacial mineral deposits}

Description. Segment A (Fig. 4) consists of 3 lithostratigraphic units (coded, from bottom to top, as A1, A-2, and A-3). These deposits are up to $3 \mathrm{~m}$ thick and form the central island ( $=$ a part of the higher terrace of the Horodyska River). Unit A-1 is composed of mediumgrained sands and sands with dispersed opoka gravels, with weakly visible planar cross-stratification ( $\mathrm{Sp}$, (GSp)); their thickness in the exposure is about $0.5 \mathrm{~m}$. Sands of unit A-1 gradually pass upwards into $2.5 \mathrm{~m}$ thick sandy-silty rhythmite (unit A-2). Rhythmite consists of alternating, thin $(0.5-1.0 \mathrm{~cm})$ sets of fine-grained sands and silts with horizontal lamination (Sh, Fh). The top part of segment A, distinguished as unit A-3, is composed of humus fine-grained sands with massive structure $(\mathrm{SCm})$.

Interpretation. The deposit succession is a record of the last development stage of transverse bar in sand-bed braided river. Bottom sands with weakly rounded opoka gravels and with planar cross-stratification should be related to gradual decrease of floodwater energy and associated development of progradational fronts (the origin of unit A-1). Gradual transition to sandy-silty rhythmite with horizontal stratification (unit A-2) suggests gradual decrease of dispersed flow (fine-grained sands) to its complete disappearance, and deposition from suspension (silts). The origin of unit A-3 should be related to post-depositional stabilization of bar and intensive development of pedogenesis.

\section{Segment B - Holocene biogenic and mineral deposits}

Description. Segment B is composed of the Holocene biogenic and mineral deposits filling the valley bottom (Fig. 4). Their thickness reaches up to $6 \mathrm{~m}$. In segment B there were distinguished 6 main units, coded in stratigraphic order from B-1 to B-6. The bottom part of segment (unit B-1), directly overlying horizontally stratified silts or/and sands (Sh, Fh) of unit A-2, is continuous series of detritus and detritus-calcareous gyttja with weakly visible horizontal lamination (FCh). Its thickness changes from $0.1 \mathrm{~m}$ in the gap section of the valley bottom to 2.2. $\mathrm{m}$ in the wide middle section of the Horodyska River valley (Fig. 4). Gyttja gradually passes upwards into massive peat $(\mathrm{Cm})$. It is sedge-moss (1.0-2.0 $\mathrm{m})$ or/and sedge-reed $(2.0-4.0 \mathrm{~m})$ peat of unit B-2. In narrow zone of the main (=western) palaeochannel these peats pass laterally into very sandy organic silts with weakly visible ripple structure ( $\mathrm{SCr}$ ) of unit B-3, and next into varigrained sands with ripple stratification $(\mathrm{Sr})$ of unit B-4. Peats are overlain by continuous series of detritus and/or detritus-calcareous gyttja with indistinct horizontal stratification (FCh) of unit B-5; its thickness changes from $0.5 \mathrm{~m}$ in the northern part of the wide val- ley of the Horodyska River to $1.5 \mathrm{~m}$ in its southern part (directly adjacent to the gap). The top part of segment B is composed of valley sedge and sedge-reed peats (unit B6) with the thickness of up to $0.7 \mathrm{~m}$.

Interpretation. The deposit succession records a complex course of morphogenetic processes connected with the formation and filling of the valley bottom in Holocene. The occurrence of gyttja continuous series in the bottom part of segment B (unit B-1) indicates temporary stagnation of water on the wide valley bottom and flow concentration in two narrow, simultaneously functioning river channels (units B-3 and B-4). Gradual vertical transition from detritus gyttja to valley peats of unit B-2 indicates a change of sedimentation environment from limnic to paludic and suggests gradual lowering of groundwater level within the whole valley bottom. Another gyttja succession (unit B-5) on valley sedge peats, its sedimentation continuity, and distinct lithologic boundary between both units suggest a rapid and considerable (probably intentional) rise of water level. A considerable thickness of sedimentary series indicates long-lasting functioning of water reservoir in the valley middle reaches. The upper sedge and sedge-reed peats of unit B-6 evidence gradual shallowing to complete disappearance of the reservoir and its associated new paludification of deposition environment.

\section{Palynological analyses}

The results are presented as the percentage pollen diagram (Fig. 5) drawn using the POLPAL software (Walanus and Nalepka, 1999). The diagram is divided into nine biostratigraphic units (two additional subzones coded A-B are distinguished in zones $\mathrm{H} 7$ and H8), i.e. local pollen assemblage zones (L PAZ) (West, 1970; Janczyk-Kopikowa, 1987). The boundaries of zones and subzones are determined based on the increase or decrease of percentage curves of main trees. Main features of pollen spectra in the distinguished zones $\mathrm{H} 1-\mathrm{H} 9$ are additionally presented in Table 1.

\section{Radiocarbon dating}

The results of radiocarbon dating of biogenic deposits and wood are presented in Table 2.

\section{TL dating}

The results of TL dating of pottery and valley deposits are presented in Table 3.

\section{PALAEOENVIRONMENTAL RECONSTRUC- TION OF THE FLUVIAL LANDSCAPE IN THE HORODYSKA RIVER VALLEY}

\section{Late Glacial}

Sedimentological premises (lithofacial characteristics of valley detritus deposits) and the results of TL dating indicate that the Horodyska River was braided river till the end of the Younger Dryas. In its middle reaches it had low dynamics due to low hydraulic gradients and banking up of water forced by valley morphology. Low energy flows resulted in the dominance of fine sand and silt deposits. The Pleistocene aggradation in the valley reached 205-210 $\mathrm{m}$ a.s.1. 
Table 1. Description of the pollen assemblage zones of the Hor-8 core

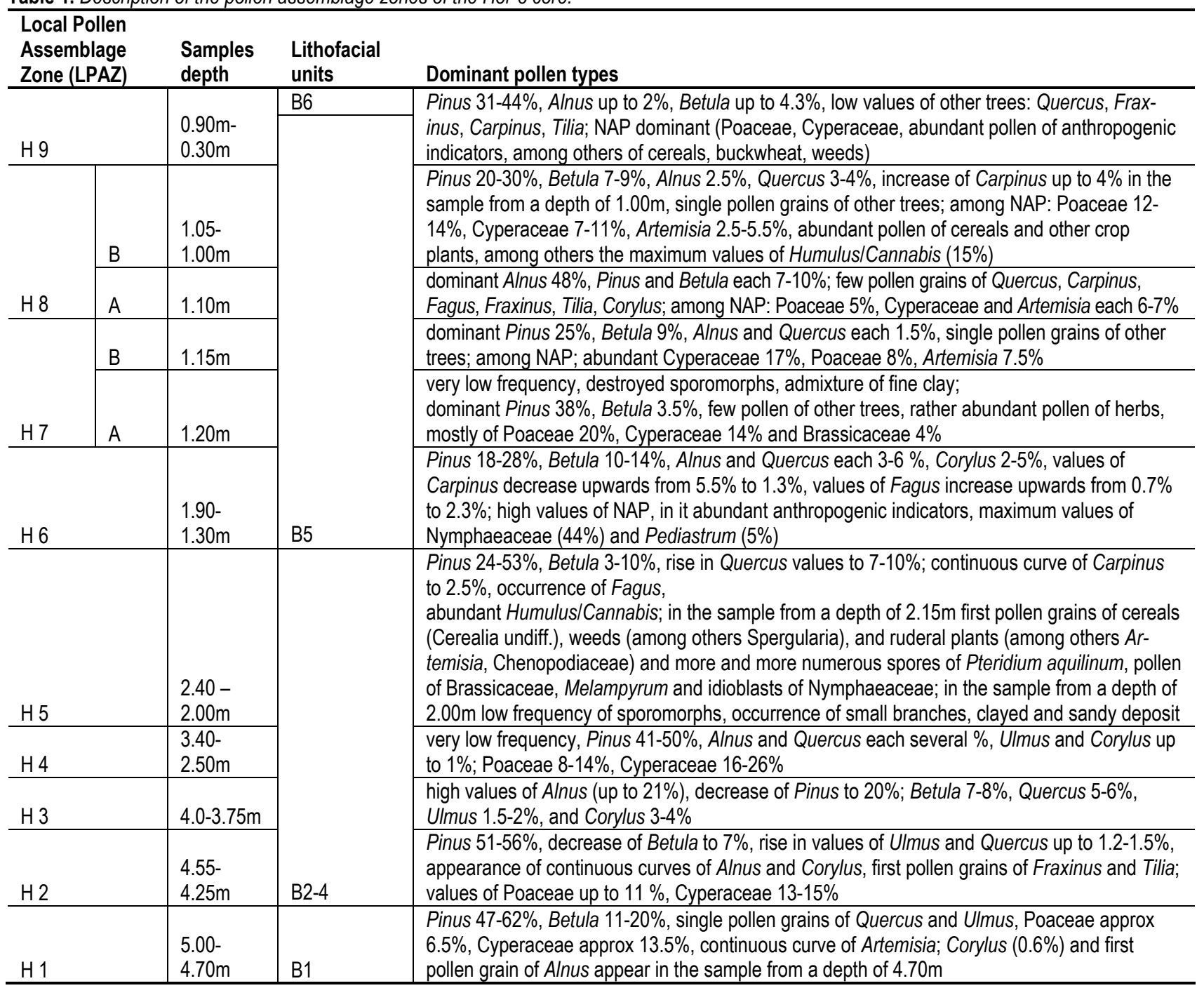

\section{Preboreal}

Gradual warming at the turn of the Younger Dryas and Preboreal and the resulting permafrost degradation influenced the reorganization of fluvial processes, in it also transformation of channel pattern. Lowering base level of erosion resulted in concentration and intensification of flow in two independently functioning channels (=forming anastomosing river pattern) separated by stable, inherited transverse bar. Western palaeochannel was the main channel, and eastern was secondary one, with gradually decreasing flow.

Results of pollen analysis, although should be treated in caution at sites situated in river valleys (Latałowa, 2003), indicate that the beginning of biogenic sedimentation in the Horodyska River valley occurred in the Preboreal period. It is confirmed, among others, by the high pollen values of Pinus and Betula, low percentages of Ulmus, and the absence of Alnus pollen in the bottom

Table 2. Radiocarbon dates collected from Hor-8 core (Horodysko site).

\begin{tabular}{|c|c|c|c|c|c|}
\hline $\begin{array}{c}\text { Sample } \\
\text { name/depth }\end{array}$ & Material & Lab. no. & Age ${ }^{14} \mathrm{C}(\mathrm{BP})$ & Calibrated age range $68 \%$ & Calibrated age range $95 \%$ \\
\hline $\begin{array}{c}\text { Hor- } 8 / 057 \\
(0.57-0.61 \mathrm{~m})\end{array}$ & detritus gyttja & Gd-17457 & $380 \pm 95$ & $\begin{array}{l}1440 \text { - } 1530 \text { AD (35.4\%) } \\
1540 \text { - } 1640 \text { AD }(32.8 \%) \\
\end{array}$ & $\begin{array}{c}1300-1700 \mathrm{AD}(93.0 \%) \\
1750-1800 \mathrm{AD}(2.4 \%) \\
\end{array}$ \\
\hline $\begin{array}{l}\text { Hor- } 8 / 100 \\
(1.00-1.05 \mathrm{~m})\end{array}$ & $\begin{array}{c}\text { wood } \\
\text { (branch) }\end{array}$ & Gd-16433 & $\begin{array}{c}\text { Modern } \\
107.4 \pm 1.2 \mathrm{pMC}\end{array}$ & $\begin{array}{c}\text { Jul } 1955 \text { - Sep } 1957(63.8 \%) \\
\text { Feb } 1996 \text { - Apr } 1996(1.7 \%) \\
\text { Feb } 1997 \text { - Jul } 1997(2.7 \%) \\
\end{array}$ & \\
\hline $\begin{array}{c}\text { Hor- } 8 / 272 \\
(2.72-2.75 \mathrm{~m})\end{array}$ & sedge-reed peat & Gd-19045 & $2700 \pm 130$ & $\begin{array}{c}1150-750 \mathrm{BC}(65.3 \%) \\
700-550 \mathrm{BC}(2.9 \%)\end{array}$ & $1300-400 \mathrm{BC}(95.4 \%)$ \\
\hline $\begin{array}{c}\text { Hor- } 8 / 498 \\
(4.98-5.00 \mathrm{~m})\end{array}$ & sedge peat & Gd-18462 & $7500 \pm 240$ & $6590-6090 \mathrm{BC}(68.2 \%)$ & $7100-5800$ BC (95.4\%) \\
\hline
\end{tabular}

Comments: $\mathrm{pMC}=$ percent of Modern Carbon 
sample of biogenic deposits. Biogenic sedimentation was a result of the disappearance of channel flow in the eastern palaeochannel that was transformed into disappearing water body. It is evidenced by the occurrence of algae coenobia (Pediastrum) and pollen of water nimfoil (Myriophyllum spicatum).

The vegetation succession recorded in pollen diagram (H1 L PAZ) started from pine-birch communities with patches of open landscape vegetation. Regularly occurring single pollen grains of elm and oak probably indicate the beginning of formation of the communities of elm riverine type in the river valley. The riverine communities included also willows (Salix) and hop (Humulus). Pollen of Cyperaceae, Filipendula and Ranunculus t. originated from the communities associated with the valley bottom of the Horodyska River. Rush vegetation near the water body was represented among others by Typha latifolia, Sparganium and Phragmites.

\section{Boreal - Older Atlantic}

At the turn of the Preboreal and Boreal paludification processes became more intensive that is reflected in lithology as gradual transition of detritus gyttja into sedge peat. Relative moistening of climate and the resulting intensification of channel flows (probably at the end of the Boreal or/and at the beginning of the Atlantic period) are recorded in the central profile (Hor-8) of the eastern palaeochannel by the occurrence of several centimetres thick clayey-silty inserts and peaty muds. Sedimentological record suggests that hiatuses occurred in this period and this is also confirmed by pollen analysis. The Boreal period is very poorly represented in the pollen diagram (Fig. 5). The zone H2 can be probably related to the Boreal period. This zone is characterized by the decrease in the birch (Betula) pollen values, the rise in the elm ( $U l$ mus) and oak (Quercus) percentage, and the appearance of ash (Fraxinus) and lime (Tilia) pollen. Pollen of hazel (Corylus), the high frequencies of which are usually thought to be indicator of the Boreal period in the area of SE Poland, is represented in the discussed diagram by the continuous but low curve.

\section{Middle Atlantic}

The record shows relatively warm and significantly wetter conditions in the Middle Atlantic period. Hydrogeological conditions changed. The eastern palaeochannel became temporarily inactive. As a result of the disappearance of concentrated flow this channel became gradually more and more boggy. This phase is documented in the lithofacial record by the $30 \mathrm{~cm}$ thick series of sedge peat with an admixture of plant detritus containing mostly Nymphaeaceae (numerous idioblasts). In the younger part of the Atlantic period, represented in the pollen diagram by the zone $\mathrm{H} 3$, the communities with dominant alder (Alnus pollen values up to $21 \%$ ) developed in the Horodyska River valley. At the same time the dry-ground oak forests with lime were present in regional vegetation as indicated by the rising values of Quercus, Corylus and the frequencies of Tilia higher than in the previous zone.

\section{Late Atlantic - Subboreal}

Since the end of the Atlantic through the whole Preboreal period, with the relative deterioration in climatic conditions, channel flows were reorganized again in the middle part of the Horodyska River valley. Numerous floods caused episodic activation of concentrated flow in the eastern palaeochannel, recorded in the profile Hor- 8 by thin clayey-silty inserts. The frequencies and preservation state of pollen representing this period (the zone $\mathrm{H} 4$ $-3.40-2.50 \mathrm{~m}$ ) are very poor. A large part of sporomorphs was probably redeposited. Only the Late Subboreal phase of considerably wetter climate and its associated another peat-forming process in the valley can be palynologically interpreted in more detail. The pollen

Table 3. Thermoluminescence dates of ceramics and fluvial sands from the New Folwark (No 5) and Horodysko (No 13) sites.

\begin{tabular}{ccccccc}
\hline Sample number & $\begin{array}{c}\text { Lab. number } \\
\text { Lub- }\end{array}$ & $\begin{array}{c}\text { Site } \\
\text { number }\end{array}$ & Material & $\begin{array}{c}\text { Annual dose } \\
\text { DR Gy/ka) }\end{array}$ & $\begin{array}{c}\text { Equivalent dose } \\
\text { ED (Gy) }\end{array}$ & $\begin{array}{c}\text { TL Age } \\
\text { (years BP) }\end{array}$ \\
\hline H/NF/1/07 & 4419 & 5 & pottery & $6.24 \pm 0.18$ & $4.40 \pm 0.17$ & $705 \pm 34$ \\
H/NF/2/07 & 4420 & 5 & pottery & $4.37 \pm 0.14$ & $5.50 \pm 0.31$ & $1258 \pm 61$ \\
H/NF/3/07 & 4421 & 5 & pottery & $5.69 \pm 0.19$ & $4.80 \pm 0.24$ & $844 \pm 50$ \\
H/NF/4/07 & 4422 & 5 & pottery & $4.74 \pm 0.15$ & $5.15 \pm 0.20$ & $1086 \pm 54$ \\
H/NF/5/07 & 4423 & 5 & pottery & $5.29 \pm 0.16$ & $4.31 \pm 0.17$ & $815 \pm 40$ \\
H/NF/6/07 & 4424 & 5 & pottery & $4.80 \pm 0.13$ & $7.67 \pm 0.32$ & $1598 \pm 77$ \\
H/NF/7/07 & 4429 & 5 & pottery & $5.54 \pm 0.17$ & $12.3 \pm 0.53$ & $2220 \pm 110$ \\
H/NF/8/07 & 4425 & 5 & pottery & $4.02 \pm 0.12$ & $14.44 \pm 0.53$ & $3590 \pm 170$ \\
H/NF/9/07 & 4426 & 5 & pottery & $5.75 \pm 0.19$ & $12.55 \pm 0.46$ & $2180 \pm 110$ \\
H/NF/10/07 & 4427 & 13 & pottery & $3.82 \pm 0.12$ & $9.60 \pm 0.35$ & $2510 \pm 110$ \\
H/NF/11/07 & 4428 & 13 & pottery & $3.55 \pm 0.11$ & $6.25 \pm 0.22$ & $1761 \pm 78$ \\
H/NF/12/07 & 4430 & 13 & pottery & $3.19 \pm 0.11$ & $4.22 \pm 0.16$ & $1323 \pm 69$ \\
H/NF/13/07 & 4432 & 13 & pottery & $4.63 \pm 0.14$ & $5.16 \pm 0.20$ & $1114 \pm 54$ \\
H/NF/14/07 & 4431 & 13 & pottery & $3.55 \pm 0.11$ & $5.81 \pm 0.21$ & $1637 \pm 79$ \\
H/NF/15/07 & 4433 & 13 & pottery & $4.22 \pm 0.13$ & $6.30 \pm 0.25$ & $1493 \pm 73$ \\
H/NF/16/07 & 4434 & 13 & pottery & $4.51 \pm 0.14$ & $5.91 \pm 0.20$ & $1310 \pm 66$ \\
H/NF/17/07 & 4435 & 13 & pottery & $3.36 \pm 0.11$ & $5.63 \pm 0.21$ & $1676 \pm 79$ \\
H/NF/18/08 & 4625 & 13 & fluvial fine-grained sand & $1.79 \pm 0.09$ & $19.3 \pm 2.4$ & $10800 \pm 1400$ \\
H/NF/19/08 & 4626 & 5 & fluvial fine-grained sand & $1.55 \pm 0.08$ & $14.8 \pm 1.8$ & $9500 \pm 1300$ \\
\hline
\end{tabular}


diagram records the appearance of new taxa in this period, i.e. hornbeam and beech in regional vegetation, and the increasing indicators of human activity in the composition of sporomorphs. Pollen grains of beech (Fagus), hornbeam (Carpinus) and fir (Abies) appear regularly in pollen spectra, from the samples from a depth of $5.05 \mathrm{~m}$ (beech and fir) and $2.75 \mathrm{~m}$ (hornbeam) upwards.

\section{Subatlantic}

Lithofacial units B-5 and B-6, and pollen zones H5H9 are related to this period (Fig. 5). Fluvial landscape changes were distinctly connected with human impact. Ash-alder riverine forests with an admixture of spruce, as well as willow shrubs occurred probably in the Horodyska River valley. At that time dry-ground forest communities with dominant hornbeam and oak could have formed in the lower parts of elevations and in the gullies cutting loess cover, and communities with beech and fir in higher (=plateau) situations. First pollen grains of cereals (Cerealia undiff.) and consistent occurrence of pollen of other synanthropic plants such as: plantain (Plantago lanceolata), cow-wheat (Melampyrum), higher values of Artemisia, Chenopodiaceae, and also grasses (Poaceae) suggest intensification of agriculture in the valley and its close vicinity. New rapid increase of anthropogenic indicators among NAP and the decrease of AP (mostly hornbeam, oak, ash) in the zone H6 (1.90$1.30 \mathrm{~m}$ ) evidence the changes resulting from strong deforestation in the early Middle Ages. The areas especially favourable to grazing occurred probably on floodplain of the Horodyska River. For this reason in the diagram the percentages of sporomorphs originated from pastures are higher than the values of pollen associated with agriculture. In the valley sedimentary succession the period of early Middle Ages is related to the beginning of lacustrine (=reservoir) deposition with very well preserved spore-pollen material typical of eutrophic water bodies. Sedimentological record indicates relatively rapid rise of the water table (probably by $1-1.5 \mathrm{~m}$ ) that could be interpreted as intentional blocking of river valley downstream of the archaeological site - in the gap section of the valley - and formation of a water reservoir (see Dulinicz and Iwaszczuk, 2008; Fig. 6). This reservoir was functioning for a rather long time (till about the 16th century) as evidence both by the succession of lacustrine deposits and the results of radiocarbon dating. The transition from peat to gyttja, i.e. the change of sedimentation from paludic to limnic (in eutrophic reservoir of stagnant water) is distinctly visible at a depth of $1.90 \mathrm{~m}$. It is also confirmed by the occurrence of Pediastrum and Tetraedron algae, pollen of Myriophyllum spicatum, and hairs of Ceratophyllum. The increased values of pollen and idioblasts of Nymphaeaceae in the younger part of the zone H6 indicate more and more eutrophic conditions probably due to the supply of nutrients from the vicinity of the settlement in the Horodysko archaeological site. The end of the water reservoir functioning, radiocarbon dated and palynologically evidenced (absence of water plants pollen), probably occurred in the 16 th century.

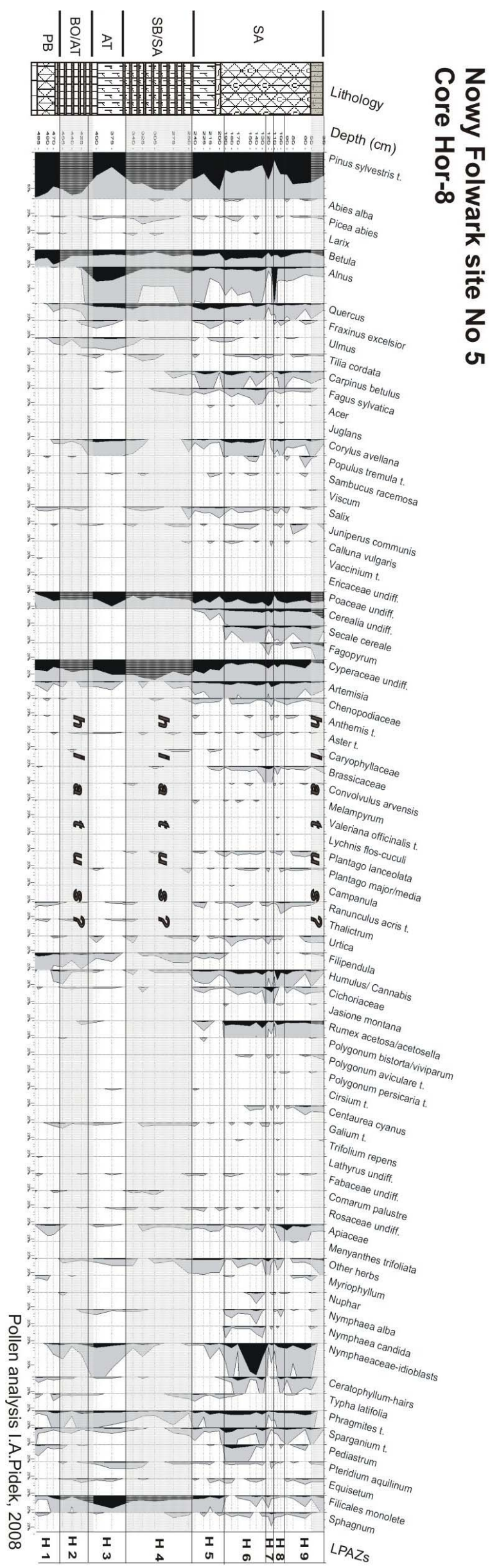

Fig. 5. Pollen diagram from the core Hor-8; location as in Fig. $1 \mathrm{C}$. 

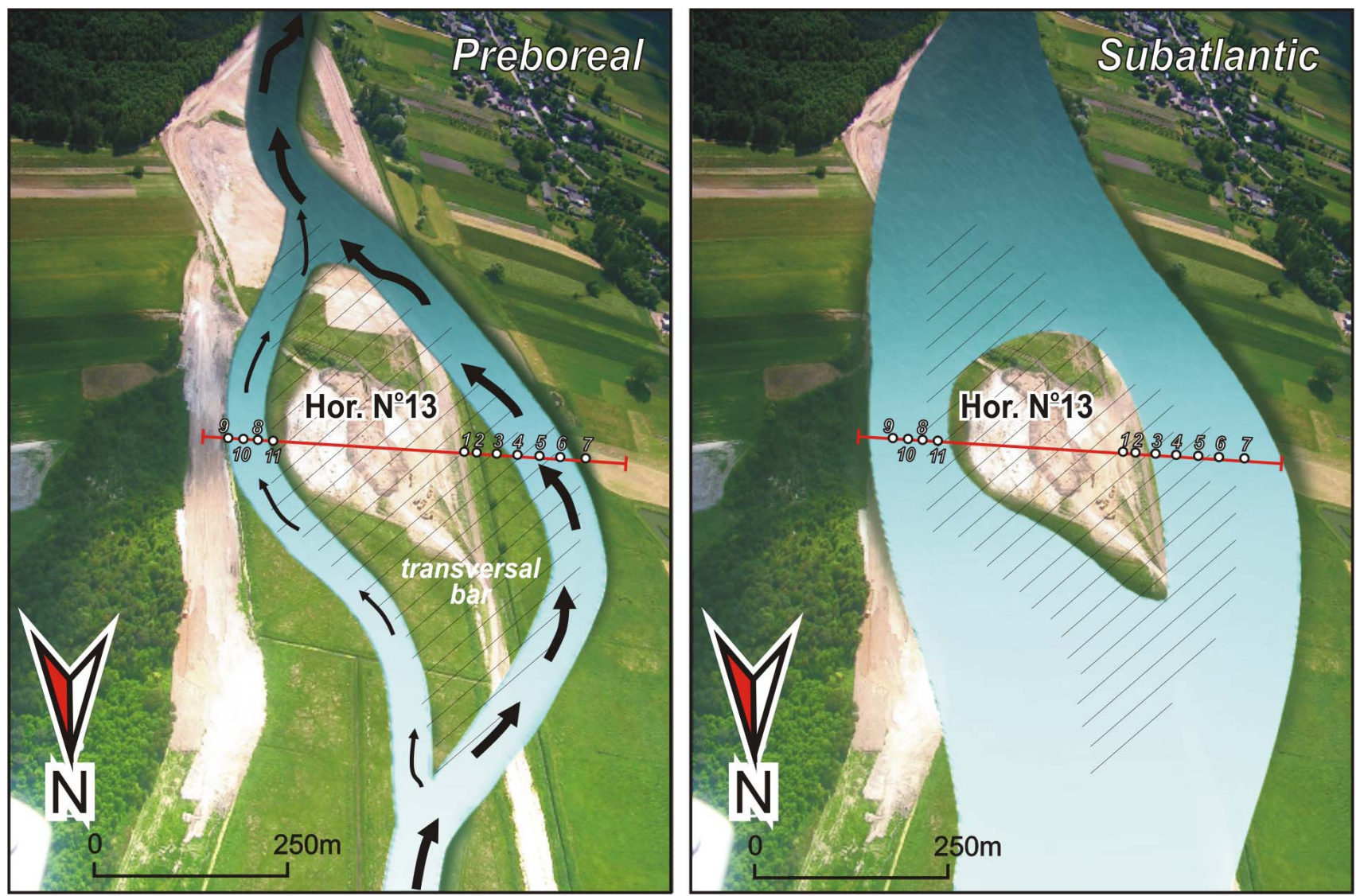

Fig. 6. Palaeogeographical reconstruction of the middle section of the Horodyska River valley in Preboreal (A) and Subatlantic (B).

\section{DISCUSSION AND CONCLUSIONS}

The results of interdisciplinary palaeoenvironmental studies in the Horodyska River valley near the multicultural archaeological sites enabled to prove the main phases of the Holocene (natural and anthropogenic) environmental changes, both in local and regional scale. However, their record in deposits and the resulting interpretation possibilities are very different.

The most complete palaeoenvironmental records represent the periods where the eastern palaeochannel was passive and functioned as a closed (dammed) lake. Gyttja and quasi-lacustrine deposits (=peat with gyttja admixture) formed in these periods are palynologically and/or chronostratigraphically related to (1) Preboreal, (2) middle Atlantic, and (3) early and middle Subatlantic. Biogenic deposits sedimented in two first periods are thin and probably contain a hiatus connected with periodic functioning of (flood?) flow but enable to reconstruct a general view of fluvial landscape together with its regional background, connected almost entirely with natural environmental changes (mainly climatic ones). Similar periodicity of fluvial phenomena, recorded in river valleys of Central and Eastern Europe, is provided among others by Starkel $(2005,2006)$ and Kalicki (2006, 2007). From the beginning of the Subatlantic the record of environmental changes in valley deposits bears the mark of human impact. It is mostly manifested by consistently increasing pollen values of synanthropic plants (=intensification of agricultural activity), and from the phase SA-2 (sensu Starkel, 1977) - also by a slow change of sedimentation style, i.e. the increasing admixture of gyttja in peat, in the middle, basin-shaped widening of the Horodyska River valley. Lake nature of the middle section of the Horodyska River valley is especially well recorded in the deposits related to the early Middle Ages (=occurrence of continuous series of detritus-calcareous gyttja). Based on pollen succession, it seems that this period was warm and relatively dry. These conditions were favourable to the development of settlement in the valley bottom that is well documented in the site No13. Intensive settlement of river valley bottoms was common in the whole Central Europe in this period. Settlements were not only located on higher terraces but also in lower hypsometric positions - on floodplains, and they generally functioned till the end of the 11 th century, i.e. till the phase of considerably wetter climate (Podwińska, 1971; Rozwałka, 1997; Dulinicz, 2001; Dobrzańska and Kalicki, 2003; Stupnicka et al., 2006). This was also case of the Horodyska River valley. Distinct disturbances of sedimentation style are visible in the lacutrine series correlated with this period. Clay admixture in biogenic deposits and poor frequency of sporomorphs in the zone $\mathrm{H} 8$ of pollen diagram indicate that water conditions in the Horodyska River catchment were significantly reorganized due to a considerable increase of humidity in overregional scale (Dobrzańska and Kalicki, 2003; 2004; Kalicki, 2006; Stupnicka et al., 2006). This reorganization was manifested by a considerable rise of groundwater level and/or flow activation in the passive eastern 
palaeochannel. Similarly as in other medieval archaeological sites in Central Europe (among others Berglund, 2003; Zolitschka et al., 2003), this fact was important for settlement. River valley bottoms were abandoned, and settlements were moved to higher hypsometric positions, usually on plateaux (Noryśkiewicz, 2004; Stupnicka et al., 2006). The foundation of the Maczuły stronghold on loess plateau in the immediate vicinity of the Horodyska River valley was also dated to this period (Poleski, 2004; location as in Fig. 1, 2). The dammed water reservoir was still functioning (probably even till the end of the 16th century) but its main function was probably changed from strategic-defensive into economic.

The gathered documentation material enables us to make the following generalizations concerning the climate - settlement relations occurring in the Horodyska River valley during the last $10 \mathrm{ka}$.

Relatively dry climate and associated low groundwater level, as well as small discharge and low flows in river, permitted to settle the valley bottom and to locate human settlements on well-preserved fragments of higher terrace within the valley bottom. This occurred in the following periods and is related to the following settlement phases: Neolithic, Bronze Age, Halstadt period, period of Roman influence, early Middle Ages.

Considerably wetter climate and associated rise of groundwater level forced people to move settlements on the loess plateau at the turn of the 11 th and 12 th centuries.

\section{ACKNOWLEDGEMENTS}

This work has been supported financially by the grant of the Ministry of Culture and National Heritage within the Operation Programme "Cultural Heritage" priority 4 "Protection of Archaeological sites" (years 2006-2007). We owe gratitude to M.Sc. Andrzej Bronicki from the Museum of Chełm and Dr Halina Taras and Dr Anna Zakościelna from the Institute of Archaeology UMCS in Lublin for their help in chronology determination. TL datings were kindly provided by Dr Jarosław Kusiak in the Department of Physical Geography and Palaeogeography, Institute of Earth Sciences, Maria CurieSkłodowska University, Lublin.

\section{REFERENCES}

Berglund BE, 2003. Human impact and climate changes-synchronous events and a causal link? Quaternary International 105 (1): 7-12. DOI 10.1016/S1040-6182(02)00144-1.

Berglund BE, Ralska-Jasiewiczowa M, 1986. Pollen analysis and pollen diagrams. In: Berglund BE, ed., Handbook of Holocene Palaeoecology and palaeohydrology. Chichester, John Willey \& Sons: 455-484.

Buko A, Dzieńkowski T and Kusiak J, 2008. Próba datowania ceramiki wczesnośredniowiecznej metodą termoluminescencji: przykład badań zespołu grodowego w Busównie (An attempt at dating of Early Medieval ceramics by thermoluminescence method: a case study from the Busówno stronghold complex). Archeologia Polski, LIII (1): 25-49 (in Polish).

Cieśliński S, Rzechowski J, 1997. Mapa Geologiczna Polski, 1:200000, ark. Chetm, Horodto. (Geological Map of Poland, 1:200000, Chełm, Horodło sheet). Warszawa, Wydawnictwo Kartograficzne Polskiej Agencji Ekologicznej S.A. (in Polish).
Chudziak W, Noryśkiewicz AM and Noryśkiewicz B, 2004. Zasiedlenie Góry św. Wawrzyńca w ostatnich trzech tysiącach lat w świetle historii roślinności (The settlement of the vicinities of Saint Lawrence mountain in the last three thousand years in the light of the history of local vegetation). In: Chudziak W, ed. Mons Sancti Laurenti 2. Toruń, Uniwersytet Mikołaja Kopernika: 209-229 (in Polish).

Dobrzańska H and Kalicki T, 2003. Człowiek i środowisko w dolinie Wisły koło Krakowa w okresie od I do VII w. n.e. (Man and environment in the Vistula River Valley from the 1st to the 7th century AD). Archeologia Polski 48(1-2): 25-55 (in Polish).

Dobrzańska H and Kalicki T, 2004. Man and Environment in the Vistula River Valley near Cracow from the 1 st to the 7 th century AD. In: Dobrzańska H, Jerem E and Kalicki T, eds., The geoarchaeology of river valleys, Archaeolinqua, Ser.Minor. 18: 105-141.

Dulinicz M, 2001. Kształtowanie się Słowiańszczyzny PótnocnoZachodniej (The North-West Slavic formation). Warszawa, Instytut Archeologii i Etnologii PAN: 323pp (in Polish).

Dulinicz M and Iwaszczuk I, 2008. Interdyscyplinarne badania wybranych wczesnośredniowiecznych stanowisk z Mazowsza (Interdisciplinary investigations of selected Medieval sites from Mazowsze region). In: Chudziak W, ed., Człowiek i środowisko przyrodnicze we wczesnym średniowieczu $w$ świetle badań interdyscyplinarnych. Toruń: 149-170 (in Polish).

Eyles N, Eyles CH and Miall AD, 1983. Lithofacies types and vertical profile models; an alternative approach to the description and environmental interpretation of glacial diamictite sequences. Sedimentology 30 (3): 393-410, DOI 10.1111/j.1365-3091.1983.tb00679.x.

Hoczyk-Siwkowa S, 2006. Kotlina Chodelska we wczesnym średniowieczu. Studium archeologiczno-osadnicze. (The Chodel Basin in Early Medieval Times. An archaeological settlement study). Lublin, UMCS University Press: 151pp (in Polish).

Janczyk-Kopikowa Z, 1987. Uwagi na temat palinostratygrafii czwartorzędu (Remarks on the Quaternary palynostratigraphy). Geological Quarterly 31: 155- 163 (in Polish).

Kalicki T, 1996. Overbank deposits as indicators of the changes in discharges and supply of sediments in the upper Vistula valley the role of the climate and human impact. In: Evolution of the Vistula river valley during the last 15000 years, part VI, Wrocław. Geographical Studies, Special Issue 9: 43-60.

Kalicki T, 2006. Zapis zmian klimatu oraz działalności człowieka i ich rola w holoceńskiej ewolucji dolin środkowoeuropejskich (Reflection of climatic changes and human activity and their role in the Holocene evolution of Central European valleys). Prace Geograficzne 204: 1-347 (in Polish)

Kalicki T, 2007.Wpływ zmian klimatu i działalności człowieka na aktywizację procesów fluwialnych i eolicznych w dorzeczu Niemna (Białoruś) (Influence of climate and man changes on fluvial and aeolian processes at Niemen Basin (Belarus). In: Sołtysik R, ed., Systemy dolinne i ich funkcjonowanie, Prace Instytutu Geografii Akademii Świętokrzyskiej w Kielcach 16: 187-203 (in Polish).

Latałowa M, 2003. Holocen (Holocene). In: Dybova-Jachowicz S, Sadowska A, eds., Palinologia. Kraków, Institute of Botany, Polish Academy of Sciences: 273-292.

Łanczont M, Nogaj-Chachaj J and Klimek K, 2006. Z badań nad geomorfologicznymi skutkami osadnictwa wczesnośredniowiecznego na Wysoczyźnie Kańczuckiej (przedpole Karpat) (Investigations on the geomorphologic results of Medieval settlement on Wysoczyzna Kańczucka). In: Gancarski J, ed., Wczesne średniowiecze w Karpatach Polskich (Early Middle Ages in Polish Carpathians), Krosno: 338-354.

Marszałek S, 2004. Objaśnienia do Szczegółowej mapy geologicznej Polski, 1:50 000, ark. Kraśniczyn (Description to the Deatiled Geological Map of Poland, Kraśniczyn sheet). Warszawa, Polish Geological Institute: $32 \mathrm{pp}$.

Miall AD, 1977. A review of the braided river depositional environment. Earth Science Reviews 13(1): 1-62, DOI 10.1016/00128252(77)90055-1.

Miall AD, 1978. Lithofacies types and vertical profile models in braided river deposits: a Sumarry. In: Miall AD, ed., Fluvial sedimentology. Canadian Society of Petroleum Geologists, Memoir 5: 597604.

Nalepka D, 1994. Historia roślinności w Dolinie Wisły od Krakowa po ujście Raby w późnym vistulianie i holocenie (Vegetation history in the Vistula River valley from Cracow to Raba in Late Vistulian 
and Holocene). In: Starkel L and Prokop P, eds., Przemiany środowiska przyrodniczego Karpat (Changes in natural environment of the Carpathians). Conference Papers 20. Warszawa, IG i PZ PAN: 19-32.

Noryśkiewicz AM, 2004. Przemiany w szacie roślinnej okolic Uścia w okresie ostatnich dwóch tysięcy lat (Changes in vegetation in Uście surroundings during last two thousand years). In: Chudziak W, ed., Wczesnośredniowieczny zespół osadniczy w Kałdusie. Studia przyrodniczo-archeologiczne (Early Medieval settlement in Kałdus. Natural-archaeological studies), Toruń: 151-163.

Nowaczyk B and Okuniewska- Nowaczyk I, 1991. Lusatian stronghold in Wicina: geological and pollen analytical data. In: Kovar-Eder J, ed., Proceedings of the Pan-European Palaeobotanical Conference, Vienna, 19-23 September 1991: 39-44.

Okuniewska I and Tobolski K, 1981. Wstępne wyniki badań paleobotanicznych z dwóch paleomeandrów w dolinie Warty koło Poznania (Preliminary results of palaeobotanical investigations in two palaeomeanders in Wartha River valley near Poznań). Badania Fizjograficzne Nad Polska Zachodnia 34, ser. A, Geografia Fizyczna: 149-160.

Podwińska Z, 1971. Zmiany form osadnictwa wiejskiego na ziemiach polskich we wcześniejszym średniowieczu (Changes of settlement forms in the Polish territory during Middle Ages). Wrocław, Ossolineum: 390pp.

Poleski J, 2004. Wczesnośredniowieczne grody $w$ dorzeczu Dunajca (Early Medieval towns in the Dunajec River catchment). Kraków, Uniwersytet Jagielloński, Instytut Archeologii: 507pp (in Polish).

Rozwałka A, 1997. Lubelskie wzgórze staromiejskie w procesie formowania sie średniowiecznego miasta (The Lublin Old Town Hill in the process of Medival town formation). Lublin: 102pp (in Polish).

Starkel L, 1977. Paleogeografia holocenu (Palaeogeography of the Holocene). Warszawa, PWN: 362pp (in Polish).

Starkel L, 2002. Change in the frequency of extreme events as the indicator of climatic change in the Holocene (in fluvial systems). Quaternary International 91(1): 25-32, DOI 10.1016/S10406182(01)00099-4

Starkel L, 2005. Role of climatic and anthropogenic factors accelareting soil erosion and fluvial activity in Central Europe. Studia Quarternaria 22: 27-33.

Starkel L, 2006. Problems of Holocene climatostratigraphy on the territory of Poland. Studia Quaternaria 23: 17-21.

Stupnicka E, Baranowski T, Bender W, 2006. Wpływ czynników klimatycznych na procesy osadnicze w dolinach rzek środkowej Polski w okresie rzymskim i we wczesnym średniowieczu (The influence of climatic factors on settlement processes in the river valleys of Central Poland in the Roman and Early Medieval periods). Archeologia Polski 51(1-2): 93-120 (in Polish).

Tobolski K, 2000. Przewodnik do oznaczania torfów i osadów jeziornych. (Handbook to the determination of peat and lake deposits) Warszawa, PWN, Vademecum Geobotanicum: 508pp (in Polish).

Troels-Smith T, 1955. Karakteriserung af lose jordarter (Characterization of unconsolidated sediments). Danmarks Geologiske Undersøgelse 4 (3/10): 1-73 (in Danish).

Walanus A and Nalepka D, 1999. POLPAL Program for counting pollen grains, diagrams plotting and numerical analysis. Acta Palaeobotanica, Supplementum 2: 659-661.

West RG, 1970. Pollen zones in the Pleistocene of Great Britain and their correlation. New Phytologist 69 (4): 1179-1183, DOI 10.1111/j.1469-8137.1970.tb02498.x.

Zagórski P. 2008. Digital model of relief in the Horodyska River valley. (unpublished).

Zolitschka B, Behre KE and Schneider J, 2003. Human and climatic impact on the environment as derived from colluvial, fluvial and lacustrine archives - examples from the Bronze Age to the Migration period, Germany. Quaternary Science Reviews 22 (1): 81-100, DOI 10.1016/S0277-3791(02)00182-8. 